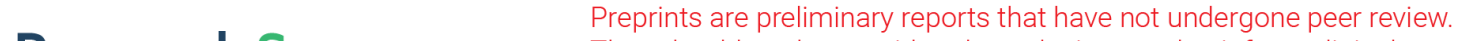 They should not be considered conclusive, used to inform clinical practice, or referenced by the media as validated information. \\ Divergent Rhodium-Catalyzed Electrochemical Vinylic C-H Annulation of Acrylamides with Alkynes
}

\section{Yi-Kang Xing}

Shanghai Institute of Organic Chemistry

\section{Xin-Ran Chen}

Zhejiang University

Qi-Liang Yang

Henan Normal University

Shuoqing Zhang

Zhejiang University https://orcid.org/0000-0002-7617-3042

\section{Haiming Guo}

Henan Normal University

\section{Xin Hong}

Zhejiang University https://orcid.org/0000-0003-4717-2814

Tian-Sheng mei ( $\nabla$ mei7900@sioc.ac.cn)

Shanghai Institute of Organic Chemistry https://orcid.org/0000-0002-4985-1071

\section{Article}

Keywords: Undivided Cell, Regioselectivities, Unsymmetrical Alkynes, Seven-membered Ring Vinylrhodium Intermediate, a-pyridones, Cyclic Imidates

Posted Date: October 26th, 2020

DOI: https://doi.org/10.21203/rs.3.rs-92513/v1

License: (c) (1) This work is licensed under a Creative Commons Attribution 4.0 International License. Read Full License

Version of Record: A version of this preprint was published at Nature Communications on February 10th, 2021. See the published version at https://doi.org/10.1038/s41467-021-21190-8. 


\section{Divergent Rhodium-Catalyzed Electrochemical Vinylic $\mathbf{C}-\mathbf{H}$ Annulation of Acrylamides with Alkynes}

Yi-Kang Xing, ${ }^{1,4}$ Xin-Ran Chen, ${ }^{2,4}$ Qi-Liang Yang, ${ }^{3,4}$ Shuo-Qing Zhang, ${ }^{2}$ Hai-Ming Guo, ${ }^{3}$ Xin Hong, ${ }^{2, *}$ and Tian-Sheng $\mathrm{Mei}^{1, *}$

${ }^{1}$ State Key Laboratory of Organometallic Chemistry, Shanghai Institute of Organic Chemistry, CAS, Shanghai, China

${ }^{2}$ Department of Chemistry, Zhejiang University, Hangzhou, 310027, China

${ }^{3}$ Henan Key Laboratory of Organic Functional Molecules and Drug Innovation, Henan Normal University, Xinxiang, Henan, China

${ }^{4}$ Contributed equally to this work

*Correspondence: hxchem@zju.edu.cn; mei7900@sioc.ac.cn

\section{Abstract}

A Rh-catalyzed electrochemical vinylic $\mathrm{C}-\mathrm{H}$ annulation of acrylamides with alkynes has been developed in an undivided cell, affording cyclic products in good to excellent yield. Divergent syntheses of $\alpha$-pyridones and cyclic imidates are accomplished by employing $\mathrm{N}$-phenyl acrylamides and N-tosyl acrylamides as substrates, respectively. Additionally, excellent regioselectivities are achieved when using unsymmetrical alkynes. This electrochemical process is environmentally benign compared to traditional transition metal-catalyzed $\mathrm{C}-\mathrm{H}$ annulations because it avoids the use of stoichiometric metal oxidants. DFT calculations elucidated the reaction mechanism and origins of substituent-controlled chemoselectivity. The sequential $\mathrm{C}-\mathrm{H}$ activation and alkyne insertion under rhodium catalysis leads to the sevenmembered ring vinyl-rhodium intermediate. This intermediate undergoes either the classic 
neutral concerted reductive elimination to produce $\alpha$-pyridones, or the ionic stepwise pathway to produce cyclic imidates.

\section{Introduction}

$\alpha$-Pyridones and $\alpha$-pyrones are ubiquitous structural motifs found in natural products and biologically active small molecules. ${ }^{1}$ Transition metal-catalyzed vinylic $\mathrm{C}-\mathrm{H}$ annulation of acrylic amides or acrylic acids with alkynes has recently emerged as one of the most powerful tools for their synthesis. ${ }^{2}$ In 2009, Miura and co-workers described an early example of Rhcatalyzed oxidative coupling of substituted acrylic acids with terminal alkynes using $\mathrm{Ag}_{2} \mathrm{CO}_{3}$ as the oxidant, affording $\alpha$-pyrones. ${ }^{3}$ Subsequently, the groups of Li and Rovis reported Rhcatalyzed vinylic $\mathrm{C}-\mathrm{H}$ annulation of acrylamides with alkynes to afford a-pyridones under elevated temperature using stoichiometric transition metal oxidants (Scheme $1 \mathrm{~A}$, left side). ${ }^{4}$ Inspired by these seminal works, various transition metal-catalyzed vinylic $\mathrm{C}-\mathrm{H}$ annulation reactions with alkynes have been developed to prepare $\alpha$-pyridones or $\alpha$-pyrones, including ones catalyzed by $\mathrm{Rh},{ }^{5} \mathrm{Ru},{ }^{6} \mathrm{Co}_{,}{ }^{7} \mathrm{Pd},{ }^{8}$ and $\mathrm{Fe}^{9}$ catalysts. Despite these advances, important challenges remain, including: 1) typically high reaction temperatures $\left.\left(100-120{ }^{\circ} \mathrm{C}\right) ; 2\right)$ stoichiometric transition metal oxidants such as $\mathrm{Cu}(\mathrm{OAc})_{2}$ or $\mathrm{AgOAc}$ are generally required to regenerate catalysts; 3) a highly selective divergent synthesis of $\alpha$-pyridones and cyclic imidates (Scheme 1A, right side) from acrylamides is still lacking. ${ }^{4 a}$

Electrochemical organic synthesis has received tremendous attention because electric current offers an environmentally benign alternative to conventional methods for oxidation and reduction of organic compounds, such as those involving chemical oxidants and reductants. ${ }^{10-}$

\footnotetext{
${ }^{12}$ Transition metal-catalyzed electrochemical arene $\mathrm{C}-\mathrm{H}$ annulation with alkynes has been
} 
A. Previous study

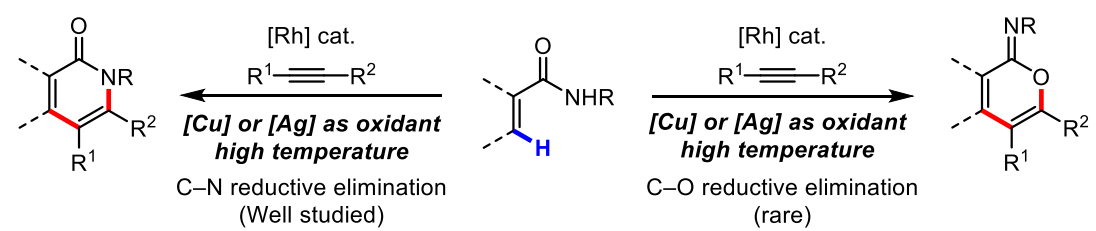

B. This work: $R$-catalyzed electrochemical vinylic $\mathrm{C}-\mathrm{H}$ annulation of acrylamides with alkynes

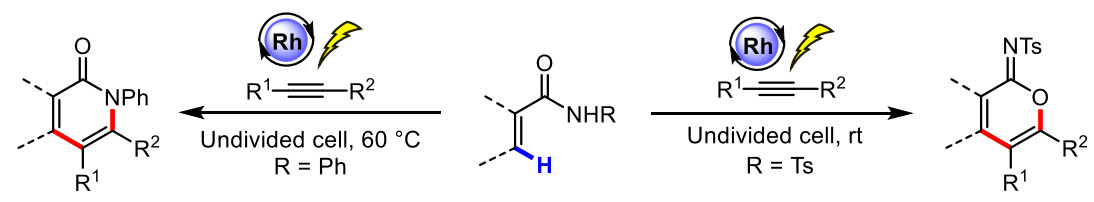

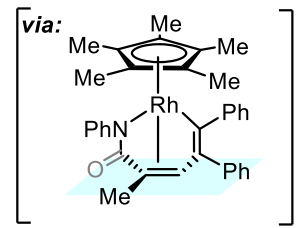

neutral concerted pathway

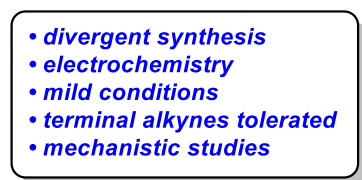

- terminal alkynes tolerated
- mechanistic studies

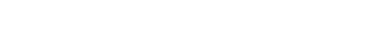

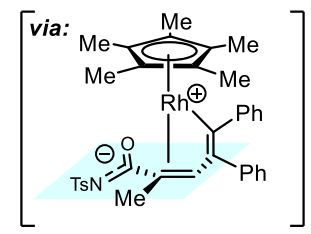

ionic stepwise pathway

\section{Scheme 1. Rh-Catalyzed Vinylic C-H Annulation of Acrylamides with Alkynes}

developed using catalysts including $\mathrm{Co},{ }^{13} \mathrm{Ru},{ }^{14} \mathrm{Rh},{ }^{15}$ and $\mathrm{Cu} .{ }^{16}$ In contrast, electrochemical vinylic $\mathrm{C}-\mathrm{H}$ annulation with alkynes is less studied. Recently, we reported an Ir-catalyzed electrochemical vinylic $\mathrm{C}-\mathrm{H}$ annulation reaction of acrylic acids with internal alkynes, affording $\alpha$-pyrones in good yields, but terminal alkynes are not tolerated. ${ }^{17}$ Subsequently, Ackermann and co-workers demonstrated Ru-catalyzed electrochemical vinylic C-H annulation of acrylamides with symmetric internal alkynes at elevated temperature $\left(140{ }^{\circ} \mathrm{C}\right) .{ }^{18}$ Herein, we report the first example of a transition metal-catalyzed electrochemical vinylic $\mathrm{C}$ $\mathrm{H}$ annulation of acrylamides with alkynes in an undivided cell under mild reaction conditions, specifically by the action of a Rh catalyst. Importantly, divergent syntheses of a-pyridones and cyclic imidates are achieved by varying the $\mathrm{N}$-substituent of the acrylamides. Furthermore, terminal alkynes are well tolerated in this Rh-catalyzed electrochemical vinylic $\mathrm{C}-\mathrm{H}$ annulation (Scheme 1B). We also probed the reaction mechanism by carrying out cyclic voltammetric analysis and kinetic isotopic experiments. Density functional theory (DFT) calculations elucidated origins of substituent-controlled chemoselectivity. The sequential $\mathrm{C}-\mathrm{H}$ activation 
and alkyne insertion under rhodium catalysis leads to the seven-membered ring vinyl-rhodium intermediate. This intermediate undergoes either the classic neutral concerted reductive elimination to produce pyridones, or the ionic stepwise pathway to produce cyclic imidates. The electronic nature of the $\mathrm{N}$-substituent has exactly the reversal effect on the rates of neutral concerted and ionic stepwise reductive elimination pathways, which switches the chemoselectivity.

\section{Results and discussion}

Optimization Studies. Initially, we probed various reaction conditions using 2methylacrylamide (1a) and diphenylacetylene (2a) as reaction partners in an undivided cell (Table 1, and see Table S1-S5 in the Supporting Information). To our delight, using $\left(\mathrm{Cp}^{*} \mathrm{RhCl}_{2}\right)_{2}$ as the precatalyst, $n-\mathrm{Bu}_{4} \mathrm{NOAc}$ as the electrolyte, and $\mathrm{MeOH}$ as the solvent in an undivided cell with two platinum electrodes under constant-current electrolysis at $1.5 \mathrm{~mA}$ for seven hours at $60{ }^{\circ} \mathrm{C}$ or room temperature, cyclic imidate 3a can be obtained in $91 \%$ isolated yield (Table 1, entry 1). Acetonitrile as solvent affords a similar yield, while yield diminishes significantly when other solvents are used (entries 2-5). Other electrolytes such as $\mathrm{NaOAc}$ and NaOPiv result in slightly lower yields (entries 6 and 7). Control experiments show that no significant amount of annulation product is produced in the absence of the catalyst or electric current (entries 8 and 9). To our delight, 92\% isolated yield is obtained when the reaction is carried out with IKA ElectraSyn 2.0 at room temperature (entry 10). ${ }^{19}$ Interestingly, switching to the synthesis of $\alpha$-pyridones instead of cyclic imidates can be achieved by simply changing the N-substitution of acrylamides (entries 11-13). $\alpha$-Pyridone $\mathbf{4 b}$ can be obtained in $95 \%$ 
isolated yield when $\mathrm{N}$-phenyl acrylamide $\mathbf{1 b}$ is used (entry 11). Other $\mathrm{N}$-aryl groups afford lower yields with good selectivity of $\alpha$-pyridones versus cyclic imidates (entries 12 and 13).

Table 1. Annulation Optimization with Acrylamide 1a and Diphenylacetylene

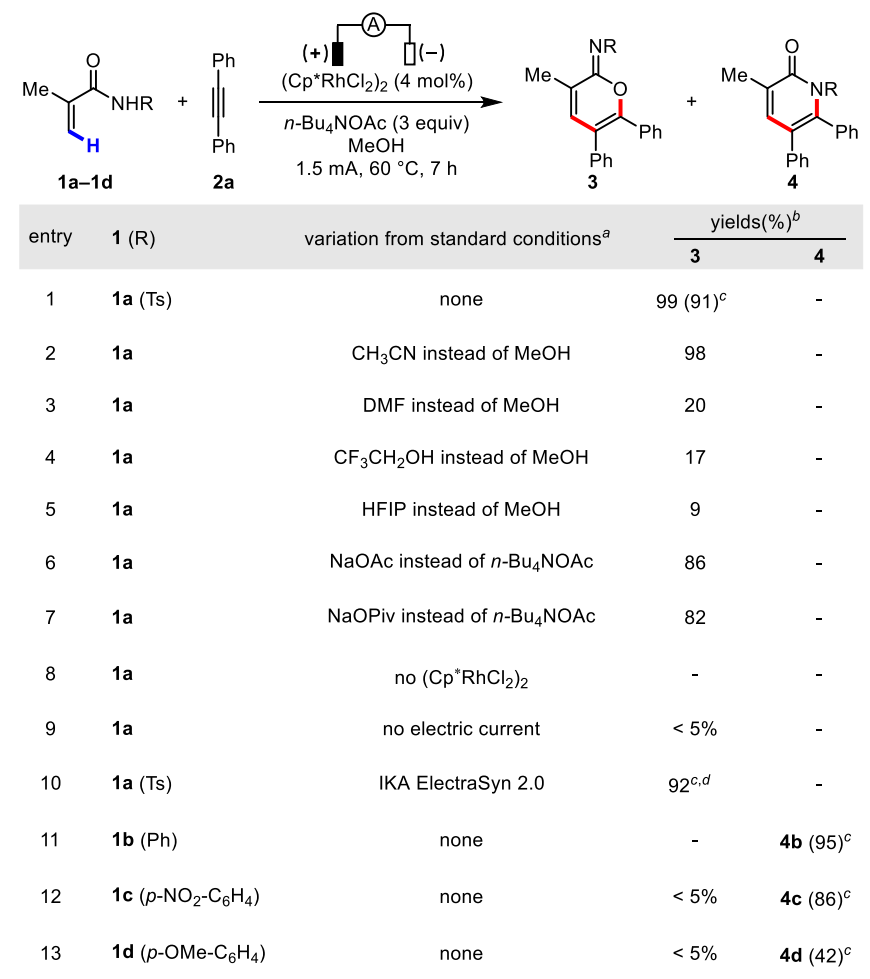

${ }^{a}$ Reaction conditions: 1 (0.3 mmol), 2a $(0.2 \mathrm{mmol}),\left(\mathrm{Cp}^{*} \mathrm{RhCl}_{2}\right)_{2}(4 \mathrm{~mol} \%), n$-Bu $4 \mathrm{NOAc}(3.0$ equiv) and $\mathrm{MeOH}(3 \mathrm{~mL})$, in an undivided cell with two platinum electrodes (each 1.0 x 1.0 $\left.\mathrm{cm}^{2}\right), 60{ }^{\circ} \mathrm{C}, 1.5 \mathrm{~mA}, 7 \mathrm{~h} .{ }^{b}$ The yield was determined by ${ }^{1} \mathrm{H}$ NMR using 1,4-dimethoxybenzene as an internal standard. ${ }^{c}$ Isolated yield. ${ }^{d}$ Room temperature.

Versatility. With the optimized reaction conditions in hand, we investigated the generality of this electrochemical $\mathrm{C}-\mathrm{H}$ annulation. As shown in Table 2A, various acrylamides substituted with alkyl, ester, ether, aryl, fluoro, chloro, and bromo groups are well tolerated, affording the corresponding cyclic imidates in good to excellent yields (3a, 6a-6r). A variety of alkynes react well, including diarylacetylenes (7a-7l) and dialkylacetylenes (7m-7o). With unsymmetrical alkynes, regioselectivity is governed by arene electronics. For example, moderate 
Table 2. Substrate Scope for Cyclic Imidate Synthesisa

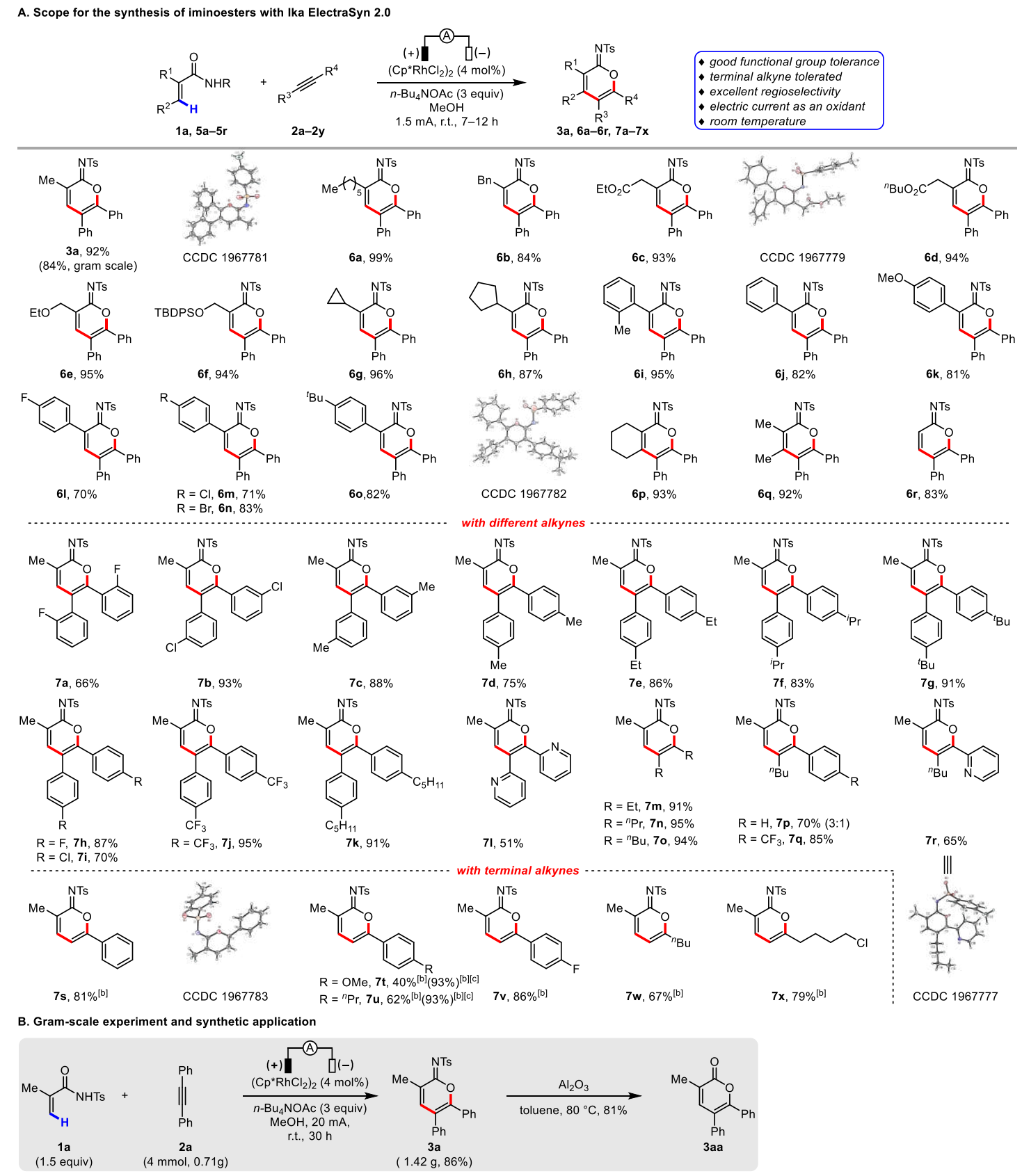

${ }^{a}$ Isolated yields are reported. Reaction conditions: 1a or $5(0.3 \mathrm{mmol}), 2(0.2 \mathrm{mmol})$, $\left(\mathrm{Cp}^{*} \mathrm{RhCl}_{2}\right)_{2}(4 \mathrm{~mol} \%), n$-Bu ${ }_{4} \mathrm{NOAc}$ (3.0 equiv), and $\mathrm{MeOH}(6 \mathrm{~mL})$ in an undivided cell with two platinum electrodes (each $\left.3.0 \times 0.8 \mathrm{~cm}^{2}\right)$, room temperature, $1.5 \mathrm{~mA}, 7-12 \mathrm{~h} .{ }^{b} \mathbf{5}(0.15 \mathrm{mmol})$, $2(0.3 \mathrm{mmol}) .{ }^{c}$ The reaction was carried out at $60^{\circ} \mathrm{C}$. 
regioselectivity is achieved with $n$-butyl phenyl acetylene (7p). In contrast, excellent regioselectivities are obtained when electron-deficient arylacetylenes are employed (7q and $\mathbf{7 r})$. In addition, excellent regioselectivities and yields are accomplished using terminal alkynes, with the alkyl or aryl groups oriented proximal to the oxygen heteroatom in the product $(7 \mathbf{s}-$ 7x). (As a reminder, terminal alkynes are not tolerated in the aforementioned Ir-catalyzed electrochemical C-H annulation. ${ }^{17}$ ) Furthermore, the structures of $3 \mathbf{3 a}, \mathbf{6 c}, \mathbf{6 o}, 7 \mathbf{r}$, and $7 \mathbf{s}$ were unambiguously verified by X-ray analysis. Finally, we demonstrated the preparative utility of this $\mathrm{Rh}$-catalyzed electrochemical $\mathrm{C}-\mathrm{H}$ annulation reaction by running a reaction containing $6.0 \mathrm{mmol}$ of substrate $\mathbf{1 a}$ and $4.0 \mathrm{mmol}$ of substrate $\mathbf{2 a}$ to afford cyclic imidate $\mathbf{3 a}$ in $84 \%$ yield, which can be further converted into $\alpha$-pyrone 3aa (Table 2B).

Table 3. Substrate Scope for $\alpha$-Pyridone Synthesis ${ }^{a}$

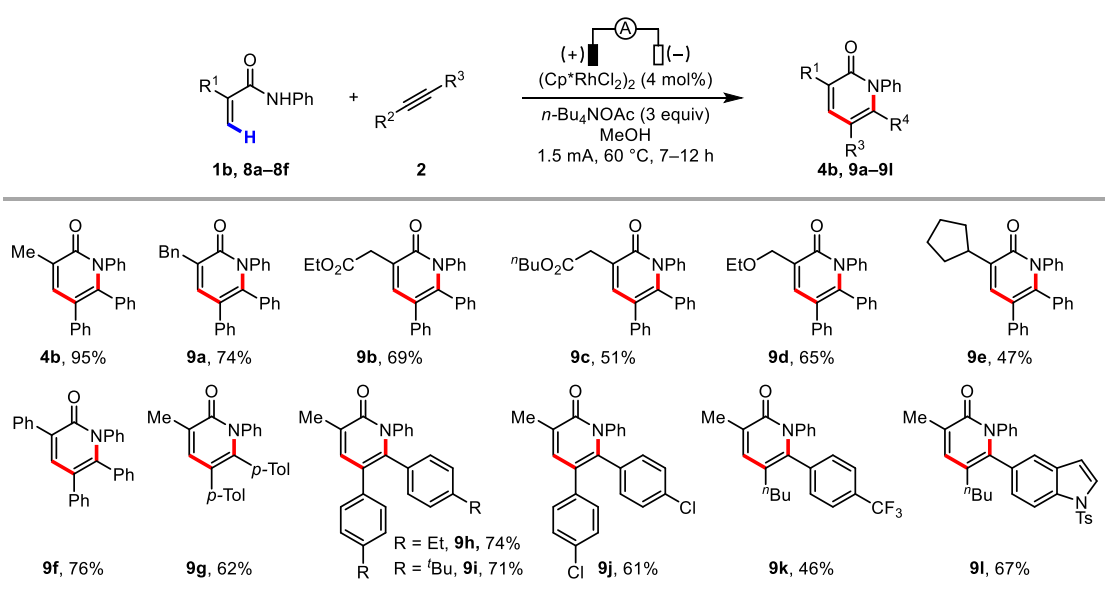

${ }^{a}$ Reaction conditions: $\mathbf{1 b}$ or $\mathbf{8}(0.3 \mathrm{mmol}), \mathbf{2}(0.2 \mathrm{mmol}),\left(\mathrm{Cp} * \mathrm{RhCl}_{2}\right)_{2}(4 \mathrm{~mol} \%), n-\mathrm{Bu}_{4} \mathrm{NOAc}$ (3.0 equiv) and $\mathrm{MeOH}(3 \mathrm{~mL})$, in an undivided cell with two platinum electrodes (each $1.0 \mathrm{x}$ $\left.1.0 \mathrm{~cm}^{2}\right), 60^{\circ} \mathrm{C}, 1.5 \mathrm{~mA}, 7-12 \mathrm{~h}$

We also examined the reactivity of a series of substituted acrylamides and alkynes for the synthesis of $\alpha$-pyridones (Table 3). Acrylamides bearing a variety of functional groups such as 
alkyl, ester, ether, and aryl are well tolerated under the standard reaction conditions, affording $\alpha$-pyridones in moderate to good yields (4b, $\mathbf{9 a}-\mathbf{9 l})$.

Mechanistic Investigation. A series of experiments were carried out to elucidate the mechanism of this electrochemical $\mathrm{C}-\mathrm{H}$ annulation reaction. First, acrylamide 1a was subjected to the electrochemical $\mathrm{C}-\mathrm{H}$ annulation reaction conditions in $\mathrm{CH}_{3} \mathrm{OD}$ in the absence of an alkyne. Significant H/D exchange was observed, indicating that the putative $\mathrm{C}-\mathrm{H}$ activation step is reversible (Scheme 2A). A kinetic isotope effect (KIE) value was determined by comparing parallel experiments using acrylamide 5e and corresponding deuterated substrate 5e-d4 (Scheme 2B). A KIE value of 1.4 was observed (see Supporting Information for details). In addition, we executed the stoichiometric reaction of acrylamides, diphenylacetylene $\mathbf{2 a}$, and $\left(\mathrm{Cp} * \mathrm{RhCl}_{2}\right)_{2}$ in the absence of electric current. To our delight, the rhodium sandwich complexes $\mathbf{1 0}$ and $\mathbf{1 1}$ were obtained in good yield, with the corresponding cyclic imidate as a neutral $\eta 4$ ligand. Their structures were unambiguously confirmed by X-ray analysis (Scheme 3A). Upon anodic oxidation, the product $\mathbf{3 a}$ is released from $\mathbf{1 0}$, and is a coordinatively saturated, 18electron complex (Scheme 3B). Additionally, 3a is obtained in good yield when a catalytic amount of $\mathbf{1 0}$ is employed, which suggests that $\mathbf{1 0}$ is a competent intermediate and catalyst in this electrochemical C-H annulation (Scheme 3C).

Complex 10 in $0.1 \mathrm{M}$ solution of $n-\mathrm{Bu}_{4} \mathrm{NPF}_{6}$ in $\mathrm{MeCN}$ exhibits the first oxidation peak at 0.70 V versus SCE (curve d, Figure 1), which is significantly lower than the oxidation potentials for the oxidation of other components in the reaction system (Figure 1). This supports the hypoethesis that the role of anodic oxidation is to oxidize a diene- $\mathrm{Rh}(\mathrm{I})$ complex to an active $\mathrm{Rh}(\mathrm{III})$ species with concomitant release of the product. 
A. $H / D$ exchange experiment

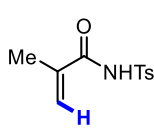

$1 \mathrm{a}$

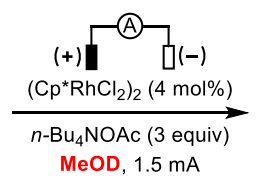

rt. $2 \mathrm{~h}$

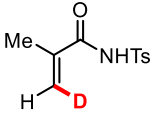

1a- $d_{1}, 95 \%$ D

B. Kinetic isotopic effect experiments

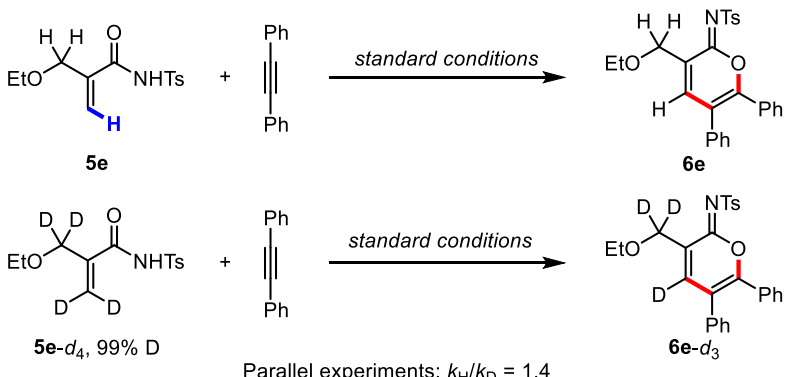

Scheme 2. H/D Exchange Experiment and Kinetic Isotopic Effect Experiments

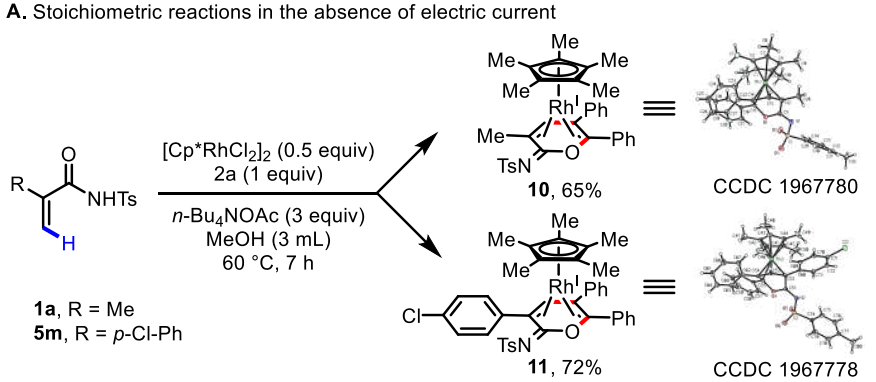

B. Anodic oxidation of complex 10

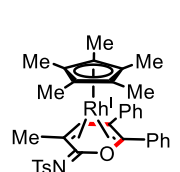

10

Catalytic reaction with complex 10

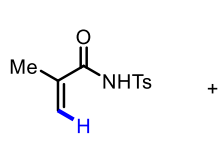

1a

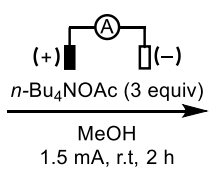

$1.5 \mathrm{~mA}$, r.t, 2

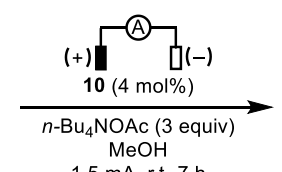

$1.5 \mathrm{~mA}$, r.t, $7 \mathrm{~h}$

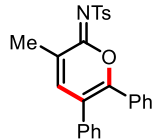

3a, $83 \%$

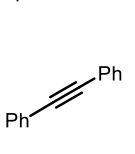

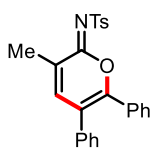

3a, $93 \%$

\section{Scheme 3. Stochiometric Reaction}

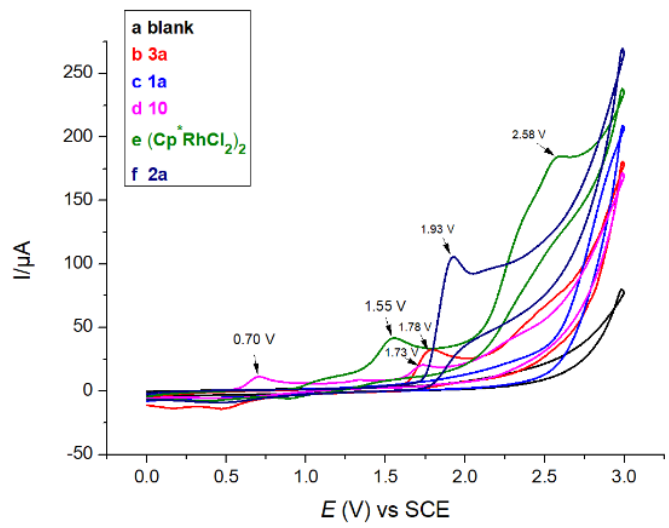


Figure 1. Cyclic Voltametric study. Cyclic voltammograms recorded on a Pt electrode (area $=0.03 \mathrm{~cm}^{2}$ ) with a scan rate of $100 \mathrm{mV} \mathrm{s}-1$ : (a) MeCN containing $0.1 \mathrm{M} n-\mathrm{Bu}_{4} \mathrm{NPF}_{6}$; (b) $\mathrm{MeCN}$ containing $0.1 \mathrm{M} \mathrm{n}-\mathrm{Bu}_{4} \mathrm{NPF}_{6}$, after addition of $4 \mathrm{mM} \mathrm{3a}$; (c) MeCN containing $0.1 \mathrm{M} n$ $\mathrm{Bu}_{4} \mathrm{NPF}_{6}$, after addition of $4 \mathrm{mM} \mathrm{1a}$; (d) MeCN containing $0.1 \mathrm{M} n-\mathrm{Bu}_{4} \mathrm{NPF}_{6}$, after addition of $4 \mathrm{mM} \mathrm{10}$; (e) $\mathrm{MeCN}$ containing $0.1 \mathrm{M} \mathrm{n}-\mathrm{Bu}_{4} \mathrm{NPF}_{6}$, after addition of $4 \mathrm{mM}$ complex $\left(\mathrm{Cp}^{*} \mathrm{RhCl}_{2}\right)_{2}$; (f) $\mathrm{MeCN}$ containing $0.1 \mathrm{M} \mathrm{n}-\mathrm{Bu}_{4} \mathrm{NPF}_{6}$, after addition of $4 \mathrm{mM} 2 \mathbf{2}$.

Computational Results. We next explored the reaction mechanism and the origins of substrate-controlled chemoselectivity through density functional theory (DFT) calculations ${ }^{20}$. From the active catalyst $\mathrm{Cp} * \mathrm{Rh}(\mathrm{OAc})_{2}$, sequential vinyl $\mathrm{C}-\mathrm{H}$ activation of $\mathrm{N}$-tosyl acrylamide 1a and diphenylacetylene insertion generate the seven-membered ring vinyl-rhodium intermediate int1 (Figure S1 and Figure 2). ${ }^{21}$ Int1 can undergo competing reductive eliminations to form either the a-pyridone product or cyclic imidate (Figure 2). The classic neutral concerted reductive elimination (red pathway) occurs through the three-membered ring transition state TS2, generating the a-pyridone product-coordinated complex int3. This neutral concerted reductive elimination requires an insurmountable barrier of $31.6 \mathrm{kcal} / \mathrm{mol}$, which is unfeasible under the experimental conditions. Alternatively, we found that the ionic stepwise pathway (black pathway) can be operative and produce the cyclic imidate product. This ionic stepwise pathway, discovered by Hong and coworkers ${ }^{22}$ in a similar Ru-catalyzed transformation, initiates through a heterolytic cleavage of the $\mathrm{Rh}-\mathrm{N}$ bond via TS5 with the assistant of methanol to generate the zwitterionic intermediate int6. From Int6, methanol dissociates to generate int7, subsequent facile $\mathrm{C}-\mathrm{O}$ bond formation through TS8 produces int9. The zwitterionic species int7 also has the possibility for $\mathrm{Rh}-\mathrm{O}$ bond formation via TS10 
(labeled in purple), but requiring a higher barrier as compared to the $\mathrm{C}-\mathrm{O}$ bond formation. Comparing the free energy barriers of the two competing pathways, the ionic stepwise reductive elimination is more favorable by $7.7 \mathrm{kcal} / \mathrm{mol}$ (TS2 vs. TS5), which is consistent with the experimental chemoselectivity favoring cyclic imidate when N-tosyl acrylamide is employed.

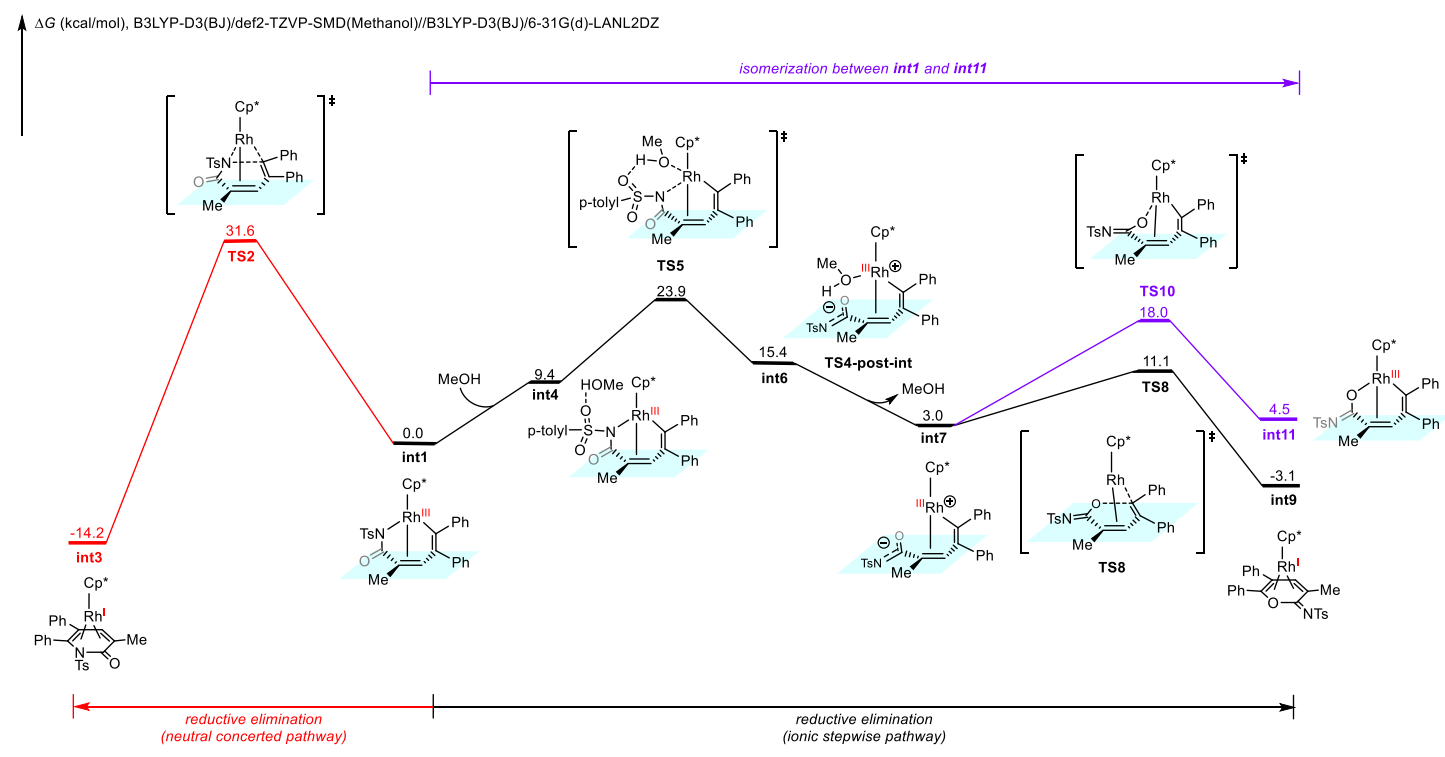

Figure 2. DFT-computed free energy changes in competing for reductive elimination pathways from seven-membered ring vinyl-rhodium intermediate when N-tosyl acrylamide 1a was employed as the substrate.

The DFT-computed free energy changes of the same competing reductive elimination pathways for the N-phenyl acrylamide $\mathbf{1 b}$ substrate are shown in Figure 5. From N-phenyl acrylamide 1b, the sequential vinyl $\mathrm{C}-\mathrm{H}$ activation and diphenylacetylene insertion generate the sevenmembered ring vinyl-rhodium intermediate int12 (Figure S2). This intermediate can undergo the classic neutral concerted reductive elimination pathway via TS13 (red pathway), with a barrier of $21.9 \mathrm{kcal} / \mathrm{mol}$. The alternative ionic stepwise pathway through TS16 is significantly less favorable due to the unstable zwitterionic species int18. Comparing to the tosyl substituent, the phenyl substituent significantly lowers the barrier of the neutral concerted pathway while 


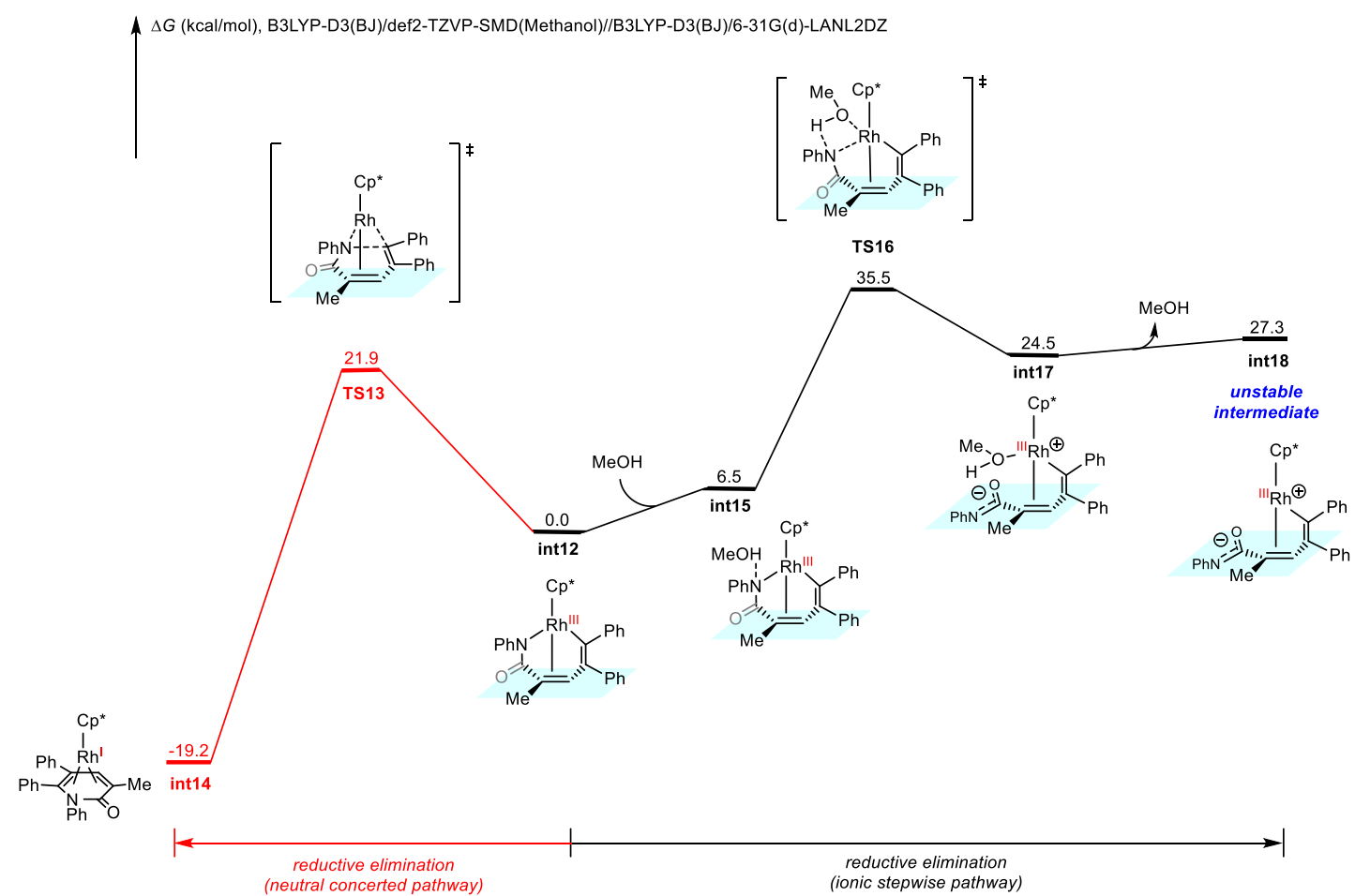

Figure 3. DFT-computed free energy changes in competing for reductive elimination pathways from seven-membered ring vinyl-rhodium intermediate int10 when N-phenyl acrylamide $\mathbf{1 b}$ was employed as the substrate.

increasing the barrier of the ionic stepwise pathway, which results in the chemoselectivity reversal. The acceleration of the neutral concerted reductive elimination by the phenyl substituent is consistent with Hartwig's previous mechanistic studies ${ }^{23}$ the electron-donating substituent on the reactive ligand undergoing reductive elimination would decrease the ionic character of the metal-ligand bond, leading to a weaker metal-ligand bond and lower reductive elimination barrier. For the ionic stepwise pathway, the stability of the zwitterionic intermediate-more specifically the stability of the anionic terminal-depends highly on the $\mathrm{N}$-substituent. The electron-donating phenyl substituent destabilizes this zwitterionic intermediate, leading to a $27.3 \mathrm{kcal} / \mathrm{mol}$ endergonic $\mathrm{Rh}-\mathrm{N}$ bond cleavage from int12 to int18 (Figure 3), while the same process is only $3.0 \mathrm{kcal} / \mathrm{mol}$ endergonic with the electron- 
withdrawing tosyl substituent (int1 to int7, Figure 2). Therefore, the electronic nature of Ts and $\mathrm{Ph} \mathrm{N}$-substituents has opposing effects on the rates of neutral concerted and ionic stepwise reductive elimination pathways, which accounts for the chemoselectivity switch. These insights provide a mechanistic basis for rational reaction design in related transformations.

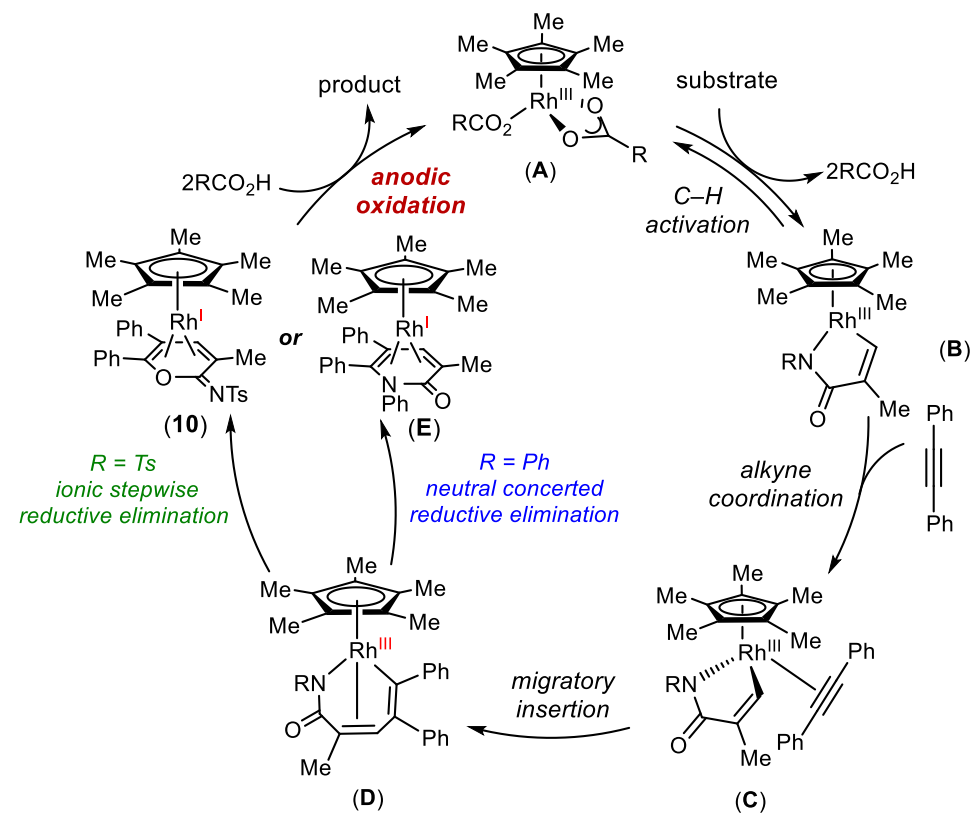

Scheme 4. Plausible Catalytic Cycle

Based on our mechanistic studies, we propose a plausible catalytic cycle as shown in Scheme

4. Initially, $\mathrm{C}-\mathrm{H}$ activation takes place to afford a cyclometallated $\mathrm{Rh}(\mathrm{III})$ intermediate $\mathbf{B}$, following ligand exchange to deliver complex $\mathbf{C}$. Next, migratory alkyne insertion results in the seven-membered rhodium complex $\mathbf{D},{ }^{24}$ which undergoes ionic stepwise or neutral concerted reductive elimination to give $\mathrm{Rh}(\mathrm{I})$ complex $\mathbf{1 0}$ or $\mathbf{E}$. Intermediate $\mathbf{1 0}$ or $\mathbf{E}$ is a coordinately saturated, 18-electron complex. Upon anodic oxidation, the product is released from $\mathbf{1 0}$ or $\mathbf{E}$, and complex $\mathbf{A}$ is regenerated.

\section{Conclusions}

In summary, we have demonstrated the first example of $\mathrm{Rh}(\mathrm{III})$-catalyzed electrochemical vinylic $\mathrm{C}-\mathrm{H}$ annulation of acrylamides with alkynes in an undivided cell under mild reaction 
conditions. Owing to the robustness of this electrochemical $\mathrm{C}-\mathrm{H}$ annulation, the reaction can be operated with IKA ElectraSyn 2.0 at room temperature, affording cyclic imidates with good to excellent yields. Additionally, divergent syntheses of a-pyridones and cyclic imidates are realized by simply switching the N-substitution of acrylamides. Furthermore, excellent regioselectivities are achieved with unsymmetrical alkynes, including terminal alkynes. Mechanistic and DFT studies combined to provide a rationale for the chemoselectivity switch and a basis for future reaction design in related transformations.

\section{EXPERIMENTAL PROCEDURES}

General Procedure for the Electrolysis. The electrocatalysis was carried out in an IKA ElectraSyn 2.0 equipped with two platinum electrodes (each $\left.0.8 \times 3.0 \mathrm{~cm}^{2}\right)$. Acrylic amide $(0.3$ mmol, 1.5 equiv), alkyne ( $0.2 \mathrm{mmol}, 1.0$ equiv), $n$-Bu${ }_{4} \mathrm{NOAc}(0.6 \mathrm{mmol}, 3.0$ equiv) and $\left(\mathrm{Cp}^{*} \mathrm{RhCl}_{2}\right)_{2}(4.0 \mathrm{~mol} \%, 99 \mathrm{wt} . \%)$ were dissolved in $\mathrm{MeOH}(6.0 \mathrm{~mL})$. Electrocatalysis was performed at room temperature with a constant current of $1.5 \mathrm{~mA}$ maintained for 7-12 h (2.03.4 $\mathrm{F} \mathrm{mol}^{-1}$ ). After the reaction, the mixture was concentrated in vacuo. The resulting residue was purified by silica gel flash chromatography to give the annulation product.

More experimental procedures and photographic guide for electrochemical $\mathrm{C}-\mathrm{H}$ annulation are provided in the Supplemental Information.

\section{Lead Contact}

Further information and requests for resources should be directed to and will be fulfilled by the Lead Contact, Tian-Sheng Mei (mei7900@sioc.ac.cn).

\section{ACKNOWLEDGMENTS}


This work was financially supported by the Strategic Priority Research Program of the Chinese Academy of Sciences (Grant XDB20000000), the NSF of China (Grants 21821002, 21772222, and 91956112), and S\&TCSM of Shanghai (Grants 17JC1401200 and 18JC1415600).

\section{AUTHOR CONTRIBUTIONS}

Y.-K.X. and Q.-L.Y. discovered the reaction. X.-R.C. and S.-Q.Z. performed the DFT calculation. H.-M.G., X.H., and T.-S.M. directed the project. Y.-K.X., X.H. and T.-S.M. wrote the manuscript with input from all authors. All authors analyzed the results and commented on the manuscript.

\section{DECLARATION OF INTERESTS}

The authors declare no competing interests.

\section{REFERENCES}

1. (a) Jessen, H. J.; Gademann, K. 4-Hydroxy-2-pyridone alkaloids: Structures and synthetic approaches. Nat. Prod. Rep. 2010, 27, 1168-1185. (b) Schäberle, T. F. Biosynthesis of apyrones. Beilstein. J. Org. Chem. 2016, 12, 571-588. (c) Lee, J. S. Recent Advances in the Synthesis of 2-Pyrones. Mar. Drugs 2015, 13, 1581-1620.

2. For selected reviews, see: (a) Duarah, G.; Kaishap, P. P.; Begum, T.; Gogoi, S. Recent Advances in Ruthenium(II)-Catalyzed $\mathrm{C}-\mathrm{H}$ Bond Activation and Alkyne Annulation Reactions. Adv. Synth. Catal. 2019, 361, 654-672. (b) Piou, T.; Rovis, T. Electronic and Steric Tuning of a Prototypical Piano Stool Complex: Rh(III) Catalysis for C-H Functionalization. Acc. Chem. Res. 2018, 51, 170-180. (c) Zheng, L.; Hua, R. C-H Activation and Alkyne Annulation via Automatic or Intrinsic Directing Groups: Towards High Step Economy. Chem. Rec. 2018, 18, 556-569. (d) Minami, Y.; Hiyama, T. Recent topics in annulation reaction via 
double $\mathrm{C}-\mathrm{H}$ bond cleavage and double $\mathrm{C}-\mathrm{C}$ bond formation. Tetrahedron Lett. 2018, 59, 781788. (e) Prakashi, S.; Kuppusamy, R.; Cheng, C.-H. Cobalt-Catalyzed Annulation Reactions via C-H Bond Activation. ChemcatChem. 2018, 10, 683-705. (f) Gulías, M.; Mascareñas, J. L. Metal-Catalyzed Annulations through Activation and Cleavage of $\mathrm{C}-\mathrm{H}$ bonds. Angew Chem. Int. Ed. 2016, 55, 11000-11019. (g) Yang, Y.; Li, K.; Cheng, Y.; Wan, D.; Li, M.; You, J. Rhodium-catalyzed annulation of arenes with alkynes through weak chelation-assisted C-H activation. Chem. Commun. 2016, 52, 2872-2884. (h) Li, S. S.; Qin, L.; Dong, L. Rhodium-catalyzed $\mathrm{C}-\mathrm{C}$ coupling reactions via double $\mathrm{C}-\mathrm{H}$ activation. Org. Biomol. Chem. 2016, 14, 4554-4570. (i) Song, G.; Li, X. Substrate Activation Strategies in Rhodium(III)Catalyzed Selective Functionalization of Arenes. Acc. Chem. Res. 2015, 48, 1007-1020. (j) Arockiam, P. B.; Bruneau, C.; Dixneuf, P. H. Ruthenium(II)-Catalyzed C-H Bond Activation and Functionalization. Chem. Rev. 2012, 112, 5879-5918. (k) Zhu, C.; Wang, T.; Falck, J. R. Amide-Directed Tandem C-C/C-N Bond Formation through C-H Activation. Chem. Asian. J. 2012, 7, 1502-1514. (1) Satoh, T.; Miura, M. Oxidative Coupling of Aromatic Substrates with Alkynes and Alkenes under Rhodium Catalysis. Chem. Eur. J. 2010, 16, 11212-11222.

3. Mochida, S.; Hirano, K.; Satoh, T.; Miura, M. Synthesis of Functionalized $\alpha$-Pyrone and Butenolide Derivatives by Rhodium-Catalyzed Oxidative Coupling of Substituted Acrylic Acids with Alkynes and Alkenes. J. Org. Chem. 2009, 74, 6295-6298.

4. (a) Su, Y.; Zhao, M.; Han, K.; Song, G.; Li, X. Synthesis of 2-Pyridones and Iminoesters via Rh(III)-Catalyzed Oxidative Coupling between Acrylamides and Alkynes. Org. Lett. 2010, 12, 5462-5465. (b) Hyster, T. K.; Rovis, T. An improved catalyst architecture for rhodium(III) 
catalyzed $\mathrm{C}-\mathrm{H}$ activation and its application to pyridone synthesis. Chem. Sci. 2011, 2, $1606-1610$.

5. For selected examples, see: (a) Tan, J.-F.; Bormann, C. T.; Severin, K.; Cramer, N. Alkynyl Triazenes as Fluoroalkyne Surrogates: Regioselective Access to 4-Fluoro-2-pyridones by a Rh(III)-Catalyzed C-H Activation-Lossen Rearrangement-Wallach Reaction. ACS Catal. 2020, 10, 3790-3796. (b) Krieger, J.-P.; Lesuisse, D.; Ricci, G.; Perrin, M.-A.; Meyer, C.; Cossy, J. Rhodium(III)-Catalyzed C-H Activation/Heterocyclization as a Macrocyclization Strategy. Synthesis of Macrocyclic Pyridones. Org. Lett. 2017, 19, 2706-2709. (c) Quiñones, N.; Seoane, A.; García-Fandiño, R.; Mascareñas, J. L.; Gulías, M. Rhodium(III)-catalyzed intramolecular annulations involving amide-directed $\mathrm{C}-\mathrm{H}$ activations: synthetic scope and mechanistic studies. Chem. Sci. 2013, 4, 2874-2879. (d) Xu, X.-X.; Liu, Y.; Park, C.-M. Rhodium(III)-Catalyzed Intramolecular Annulation through C-H Activation: Total Synthesis of ( \pm )-Antofine, $( \pm)$-Septicine, $( \pm)$-Tylophorine, and Rosettacin. Angew. Chem. Int. Ed. 2012, 51, 9372-9376. (e) Song, G.; Chen, D.; Pan, C.-L.; Crabtree, R. H.; Li, X. J. Org. Chem. 2010, 75, 7487-7490. (f) Rakshit, S.; Patureau, F. W.; Glorius, F. Pyrrole Synthesis via Allylic sp3 $\mathrm{C}-\mathrm{H}$ Activation of Enamines Followed by Intermolecular Coupling with Unactivated Alkynes. J. Am. Chem. Soc. 2010, 132, 9585-9587.

6. (a) Garad, D. N.; Mhaske, S. B. Ru-Catalyzed Regioselective Cascade Annulation of Acrylamides with 2-Alkynoates for the Synthesis of Various 6-Oxo Nicotinic Acid Esters. $J$. Org. Chem. 2019, 84, 1863-1870. (b) Petrova, E.; Rasina, D.; Jirgensons, A. NSulfonylcarboxamide as an Oxidizing Directing Group for Ruthenium-Catalyzed C-H Activation/Annulation. Eur. J. Org. Chem. 2017, 1773-1779. (c) Chinnagolla, R. K.; 
Jeganmohan, M. Regioselective synthesis of isocoumarins by ruthenium-catalyzed aerobic oxidative cyclization of aromatic acids with alkynes. Chem. Commun. 2012, 48, 2030-2032. (d) Ackermann, L.; Pospech, J.; Graczyk, K.; Rauch, K. Versatile Synthesis of Isocoumarins and $\alpha$-Pyrones by Ruthenium-Catalyzed Oxidative $\mathrm{C}-\mathrm{H} / \mathrm{O}-\mathrm{H}$ Bond Cleavages. Org. Lett. 2012, 14, 930-933. (e) Ackermann, L.; Lygin, A. V.; Hofmann, N. Ruthenium-Catalyzed Oxidative Synthesis of 2-Pyridones through $\mathrm{C}-\mathrm{H} / \mathrm{N}-\mathrm{H}$ Bond Functionalizations. Org. Lett. 2011, 13, 3278-3281.

7. (a) Liu, M.-H.; Niu, J.-L.; Yang, D.-D.; Song, M.-P. Development of a Traceless Directing Group: Cp*-Free Cobalt-Catalyzed C-H Activation/Annulations to Access Isoquinolinones. J. Org. Chem. 2020, 85, 4067-4078. (b) Mandal, R.; Sundararaju, B. Cp*Co(III)-Catalyzed Annulation of Carboxylic Acids with Alkynes. Org. Lett. 2017, 19, 2544-2547. (c) Hao, X.Q.; Du, C.; Zhu, X.-J.; Li, P.-X.; Zhang, J.-H.; Niu, J.-L.; Song, M.-P. Cobalt(II)-Catalyzed Decarboxylative $\mathrm{C}-\mathrm{H}$ Activation/Annulation Cascades: Regioselective Access to Isoquinolones and Isoindolinones. Org. Lett. 2016, 18, 3610-3613. (d) Grigorjeva, L.; Daugulis, O. Cobalt-Catalyzed, Aminoquinoline-Directed C(sp2)-H Bond Alkenylation by Alkynes. Angew. Chem. Int. Ed. 2014, 53, 10209-10212.

8. (a) Sun, Y.; Zhang, G. Palladium-Catalyzed Formal [4+2] Cycloaddition of Benzoic and Acrylic Acids with 1,3-Dienes via C-H Bond Activation: Efficient Access to 3,4Dihydroisocoumarin and 5,6-Dihydrocoumalins. Chin. J. Chem. 2018, 36, 708-711. (b) Wang, W.-G.; Peng, X.-L.; Qin, X.-Y.; Zhao, X.-Y.; Ma, C.; Tung, C.-H.; Xu, Z.-H. Synthesis of Quinolinones with Palladium-Catalyzed Oxidative Annulation between Acrylamides and Arynes. J. Org. Chem. 2015, 80, 2835-2841. (c) Yu, Y.; Huang, L.; Wu, W.; Jiang, H. 
Palladium-Catalyzed Oxidative Annulation of Acrylic Acid and Amide with Alkynes: A Practical Route to Synthesize $\alpha$-Pyrones and Pyridones. Org. Lett. 2014, 16, 2146-2149.

9. (a) Mo, J.-Y.; Müller, T. J.; Oliveira, C. A.; Demeshko, S.; Meyer, F.; Ackermann, L. IronCatalyzed C-H Activation with Propargyl Acetates: Mechanistic Insights into Iron(II) by Experiment, Kinetics, Mössbauer Spectroscopy, and Computation. Angew. Chem. Int. Ed. 2019, 58, 12874-12878. (b) Matsubara, T.; llies, L.; Nakamura, E. Oxidative C-H Activation Approach to Pyridone and Isoquinolone through an Iron-Catalyzed Coupling of Amides with Alkynes. Chem. Asian J. 2016, 11, 380-384.

10. For selected reviews, see: (a) Wang, X.-Y.; Xu, X.-T.; Wang, Z.-H. Fang, P.; Mei, T.-S. Advances in Asymmetric Organotransition Metal-Catalyzed Electrochemistry (AOMCE). Chin. J. Org. Chem. DOI: 10.6023/cjoc202003022. (b) Wang, F.; Stahl, S. S. Electrochemical Oxidation of Organic Molecules at Lower Overpotential: Accessing Broader Functional Group Compatibility with Electron-Proton Transfer Mediators. Acc. Chem. Res. 2020, 53, 561-574. (c) Siu, J. C.; Fu, N.; Lin, S. Catalyzing Electrosynthesis: A Homogeneous Electrocatalytic Approach to Reaction Discovery. Acc. Chem. Res. 2020, 53, 547-560. (d) Jing, Q.; Moeller, K. D. From Molecules to Molecular Surfaces. Exploiting the Interplay Between Organic Synthesis and Electrochemsitry. Acc. Chem. Res. 2020, 53, 135-143. (e) Kingston, C.; Palkowitz, M. D.; Takahira, Y.; Vantourout, J. C.; Peters, B. K.; Kawamata, Y.; Baran, P. S. A Survival Guide for the "Electro-curious". Acc. Chem. Soc. 2020, 53, 72-83. (f) Röckl, J. L.; Pollok, D.; Franke, R. Waldvogel, S. R. A Decade of Electrochemical Dehydrogenative C,C-Coupling of Aryls. Acc. Chem. Res. 2020, 53, 45-61. (g) Xiong, P.; Xu, H.-C. Chemistry with Electrochemically Generated N-Centered Radicals. Acc. Chem. Res. 
2019, 52, 3339-3350. (h) Yuan, Y.; Lei, A. Electrochemical Oxidative Cross-Coupling with Hydrogen Evolution Reactions. Acc. Chem. Res. 2019, 52, 3309-3324. (i) Jiang, Y.; Xu, K.; Zeng, C. Use of Electrochemistry in the Synthesis of Heterocyclic Structures. Chem. Rev. 2018, 118, 4485-4540. (j) Yan, M.; Kawamata, Y.; Baran, P. S. Synthetic Organic Electrochemical Methods Since 2000: On the Verge of a Renaissance. Chem. Rev. 2017, 117, 13230-13319. (k) Horn, E. J.; Rosen, B. R.; Baran, P. S. Synthetic Organic Electrochemistry: An Enabling and Innately Sustainable Method. ACS Cent. Sci. 2016, 2, 302-308.

11. For selected reviews, see: (a) Jiao, K.-J.; Xing, Y.-K.; Yang, Q.-L.; Qiu, H.; Mei, T.-S. SiteSelective C-H Functionalization via Synergistic Use of Electrochemistry and Transition Metal Catalysis. Acc. Chem. Res. 2020, 53, 3309-3324. (b) Ackermann, L. Metallaelectrocatalyzed C-H Activation by Earth-Abundant 3d Metals and Beyond. Acc. Chem. Res. 2020, 53, 84-104.

12. For selected examples, see: (a) Dhawa, U.; Tian, C.; Wdowik, T.; Oliveira, J. C. A.; Hao, J.; Ackermann, L. Enantioselective Palladaelectro-Catalyzed C-H Activations by Transient Directing Groups: Expedient Access to Helicenes. Angew. Chem., Int. Ed. 2020, 59, 2-9. (b) Yang, Q.-L.; Wang, X.-Y.; Weng, X.-J.; Yang, X.; Xu, X.-T.; Tong, X.; Fang, P.; Wu, X.-Y.; Mei, T.-S. Palladium-Catalyzed ortho-Selective C-H Chlorination of Arenes Using Anodic Oxidaiton. Acta Chim. Sinica 2019, 77, 866-873. (c) Qiu, Y.; Stangier, M.; Meyer, T. H.; Oliveira, J. C. A.; Ackermann, L. Iridium-Catalyzed Electrooxidative C-H Activation by Chemoselective Redox-Catalyst Cooperation. Angew. Chem., Int. Ed. 2018, 57, 14179-14183. (d) Gao, X.; Wang, P.; Zeng, L.; Tang, S.; Lei, A. Cobalt(II)-Catalyzed Electrooxidative CH Amination of Arenes with Alkylamines. J. Am. Chem. Soc 2018, 140, 4195-4199. (e) 
Shrestha, A.; Lee, M.; Dunn, A. L.; Sanford, M. S. Palladium-Catalyzed C-H Bond Acetoxylation via Electrochemical Oxidation. Org. Lett. 2018, 20, 204-207. (f) Yang, Q.-L.; Li, Y.-Q.; Ma, C.; Fang, P.; Zhang, X.-J.; Mei, T.-S. Palladium-Catalyzed C( $\left(\mathrm{sp}^{3}\right)-\mathrm{H}$ Oxygenation via Electrochemical Oxidation. J. Am. Chem. Soc. 2017, 139, 3293-3298. (g) Dudkina, Y. B.; Mikhaylov, D. Y.; Gryaznova, T. V.; Sinyashin, O. G.; Vicic, D. A.; Budnikova, Y. H. MII/MIII-Catalyzed ortho -Fluoroalkylation of 2-Phenylpyridine. Eur. J. Org. Chem. 2012, 2114-2117. (h) Kakiuchi, F.; Kochi, T.; Mutsutani, H.; Kobayashi, N.; Urano, S.; Sato, M.; Nishiyama, S.; Tanabe, T. Palladium-Catalyzed Aromatic C-H Halogenation with Hydrogen Halides by Means of Electrochemical Oxidation. J. Am. Chem. Soc. 2009, 131, 11310-11311. (i) Amatore, C.; Cammoun, C.; Jutand, A. Electrochemical Recycling of Benzoquinone in the Pd/Benzoquinone-Catalyzed Heck-Type Reactions from Arenes. Adv. Synth. Catal. 2007, 349, 292-296.

13. (a) Mei, R.; Ma, W.; Zhang, Y.; Guo, X.; Ackermann, L. Coblataelectro-Catalyzed Oxidative $\mathrm{C}-\mathrm{H} / \mathrm{N}-\mathrm{H}$ Activation with 1,3-Diynes by Electro-Removable Hydrazides. Org. Lett. 2019, 21, 6534-6538. (b) Mei, R. Sauermann, N.; Oliveira, J. C. A.; Ackermann, L. Electroremovable Traceless Hydrazides for Cobalt-Catalyzed Electro-Oxidative $\mathrm{C}-\mathrm{H} / \mathrm{N}-\mathrm{H}$ Activation with Internal Alkynes. J. Am. Chem. Soc. 2018, 140, 7913-7921. (c) Tang, S.; Wang, D.; Liu, Y.; Zeng, L.; Lei, A. Cobalt-catalyzed electrooxidative C-H/N-H [4+2] annulation with ethylene or ethyne. Nat. Commun. 2018, 9, 798-805. (d) Tian, C.; Massignan, L.; Meyer, T. H.; Ackermann, L. Electrochemical C-H/N-H Activation by Water-Tolerant Cobalt Catalysis at Room Temperature. Angew. Chem. Int. Ed. 2018, 57, 2383-2387. 
14. (a) Wang, Z.-Q.; Hou, C.; Zhong, Y.-F.; Lu, Y.-X.; Mo, Z.-Y.; Pan, Y.-M. Tang, H.-T. Electrochemically Enabled Double C-H Activation of Amides: Chemoselective Synthesis of Polycyclic Isoquinolinones. Org. Lett. 2019, 21, 9841-9845. (b) Gońka, E.; Yang, L.; Steinbock, R.; Pesciaioli, F.; Kuniyil, R.; Ackermann, L. $\pi$-Extended Polyaromatic Hydrocarbons by Sustainable Alkyne Annulations through Double $\mathrm{C}-\mathrm{H} / \mathrm{N}-\mathrm{H}$ Activation. Chem. Eur. J. 2019, 25, 16246-16250. (c) Luo, M.-J.; Zhang, T.-T.; Cai, F.-J.; Li, J.-H.; He, D.-L. Decarboxylative [4+2] annulation of arylglyoxylic acids with internal alkynes using the anodic ruthenium catalysis. Chem. Commun. 2019, 55, 7251-7254. (d) Luo, M.-J.; Hu, M.; Song, R.-J.; He, D.-L.; Li, J.-H. Ruthenium(II)-catalyzed electrooxidative [4+2] annulation of benzylic alcohols with inernal alkynes: entry to isocoumarins. Chem. Commun. 2019, 55, 1124-1127. (e) Mei, R.; Koeller, J.; Ackermann, L. Electrochemical ruthenium-catalyzed alkyne annulations by $\mathrm{C}-\mathrm{H} / \mathrm{Het}-\mathrm{H}$ activation of aryl carbamates or phenols in protic media. Chem. Commun. 2018, 54, 12879-12882. (f) Qiu, Y.; Tian, C.; Massignan, L.; Rogge, T.; Ackermann, L. Electrooxidative Ruthenium-Catalyzed C-H/O-H Annulation by Weak OCoordination. Angew. Chem. Int. Ed. 2018, 57, 5818-5822. (g) Xu, F.; Li, Y.-J.; Huang, C.; Xu, H.-C. Ruthenium-Catalyzed Electrochemical Dehydrogenative Alkyne Annulation. ACS Catal. 2018, 8, 3820-3824.

15. (a) Kong, W.-J.; Shen, Z.; Finger, L. H.; Ackermann, L. Electrochemical Access to AzaPolycyclic Aromatic Hydrocarbons: Rhoda-Electrocatalyzed Domino Alkyne Annulations. Angew. Chem. Int. Ed. 2020, 59, 5551-5556. (b) Kong, W.-J.; Finger, L. H.; Messinis, A. M.; Kuniyil, R.; Oliveira, J. C. A.; Ackermann, L. Flow Rhodaelectro-Catalyzed Alkyne Annulations by Versatile C-H Activation: Mechanistic Support for Rhodium(III/IV). J. Am. 
Chem. Soc. 2019, 141, 17198-17206. (c) Kong, W.-J.; Finger, L. H.; Oliveira, J. C. A.; Ackermann, L. Rhodaelectrocatalysis for Annulative C-H Activation: Polycyclic Aromatic Hydrocarbons through Versatile Double Electrocatalysis. Angew. Chem. Int. Ed. 2019, 58, $6342-6346$.

16. Tian, C.; Dhawa, U.; Scheremetjew, A.; Ackermann, L. Cupraelectro-Catalyzed Alkyne Annulation: Evidence for Distinct $\mathrm{C}-\mathrm{H}$ Alkynylation and Decarboxylative $\mathrm{C}-\mathrm{H} / \mathrm{C}-\mathrm{C}$ Manifolds. ACS Catal. 2019, 9, 7690-7696.

17. Yang, Q.-L.; Xing, Y.-K.; Wang, X.-Y.; Ma, H.-X.; Weng, X.-J.; Yang, X.; Guo, H.-M.; Mei, T.-S. Electrochemistry-Enabled Ir-Catalyzed Vinylic C-H Functionalization. J. Am. Chem. Soc. 2019, 141, 18970-18976.

18. Yang, L.; Steinbock, R.; Scheremetjew, A.; Kuniyil, R.; Finger, L. H.; Messinis, A. M.; Ackermann, L. Azaruthena(II)-bicyclo[3.2.0]heptadiene: Key Intermediate for Ruthenaelectro(II/III/I)-catalyzed Alkyne Annulations. Angew. Chem. Int. Ed. 2020, 59, $11130-11135$

19. Yam, M.; Kawamata, Y.; Baran, P. S. Synthetic Organic Electrochemistry: Calling All Engineers. Angew. Chem. Int. Ed. 2018, 57, 4149-4155.

20. Computations were performed with the Gaussian 09 software package; computational details are included in the Supporting Information.

21. For selected reviews on Rh-catalyzed C-H functionalization, see: (a) Rej, S.; Chatani, N. Rhodium-Catalyzed $\mathrm{C}\left(\mathrm{sp}^{2}\right)$ - or $\mathrm{C}\left(\mathrm{sp}^{3}\right)-\mathrm{H}$ Bond Functionalization Assisted by Removable Directing Groups. Angew. Chem. Int. Ed. 2019, 58, 8304-8329. (b) Song, G. Y.; Li, X. W. Substrate Activation Strategies in Rhodium(III)-Catalyzed Selective Functionalization of 
Arenes. Acc. Chem. Res. 2015, 48, 1007-1020. (c) Kuhl, N.; Schrçder, N.; Glorius, F. Formal SN-Type Reactions in Rhodium(III)-Catalyzed C-H Bond Activation. Adv. Synth. Catal. 2014, 356, 1443-1460. (d) Lewis, J. C.; Bergman, R. G.; Ellman, J. A. Direct Functionalization of Nitrogen Heterocycles via Rh-Catalyzed C-H Bond Activation. Acc. Chem. Res. 2008, 41, $1013-1025$.

22. Yu, J. L.; Zhang, S. Q.; Hong, X. Mechanisms and Origins of Chemo- and Regioselectivities of $\mathrm{Ru}(\mathrm{II})$-Catalyzed Decarboxylative $\mathrm{C}-\mathrm{H}$ Alkenylation of Aryl Carboxylic Acids with Alkynes: A Computational Study. J. Am. Chem. Soc. 2017, 139, 7224-7243.

23. (a) Hartwig, J. F. Electronic Effects on Reductive Elimination To Form Carbon-Carbon and Carbon-Heteroatom Bonds from Palladium(II) Complexes. Inorg. Chem. 2007, 46, 19361947. (b) Hartwig, J. F. Transition Metal Catalyzed Synthesis of Arylamines and Aryl Ethers from Aryl Halides and Triflates: Scope and Mechanism. Angew. Chem. Int. Ed. 1998, 37, 2046-2067.

24. (a) Han, Y.-F.; Li, H.; Hu, P.; Jin, G.-X. Alkyne Insertion Induced Regiospecific C-H Activation with [Cp*MCl2]2 (M = Ir, Rh). Organometallic 2011, 30, 905-911. (b) Li, L.; Brennessel, W. W.; Jones, W. D. An Efficient Low-Temperature Route to Polycyclic Isoquinoline Salt Synthesis via C-H Activation with [Cp*MCl2]2 (M = Rh, Ir). J. Am. Chem. Soc. 2008, 130, 12414-12419. 


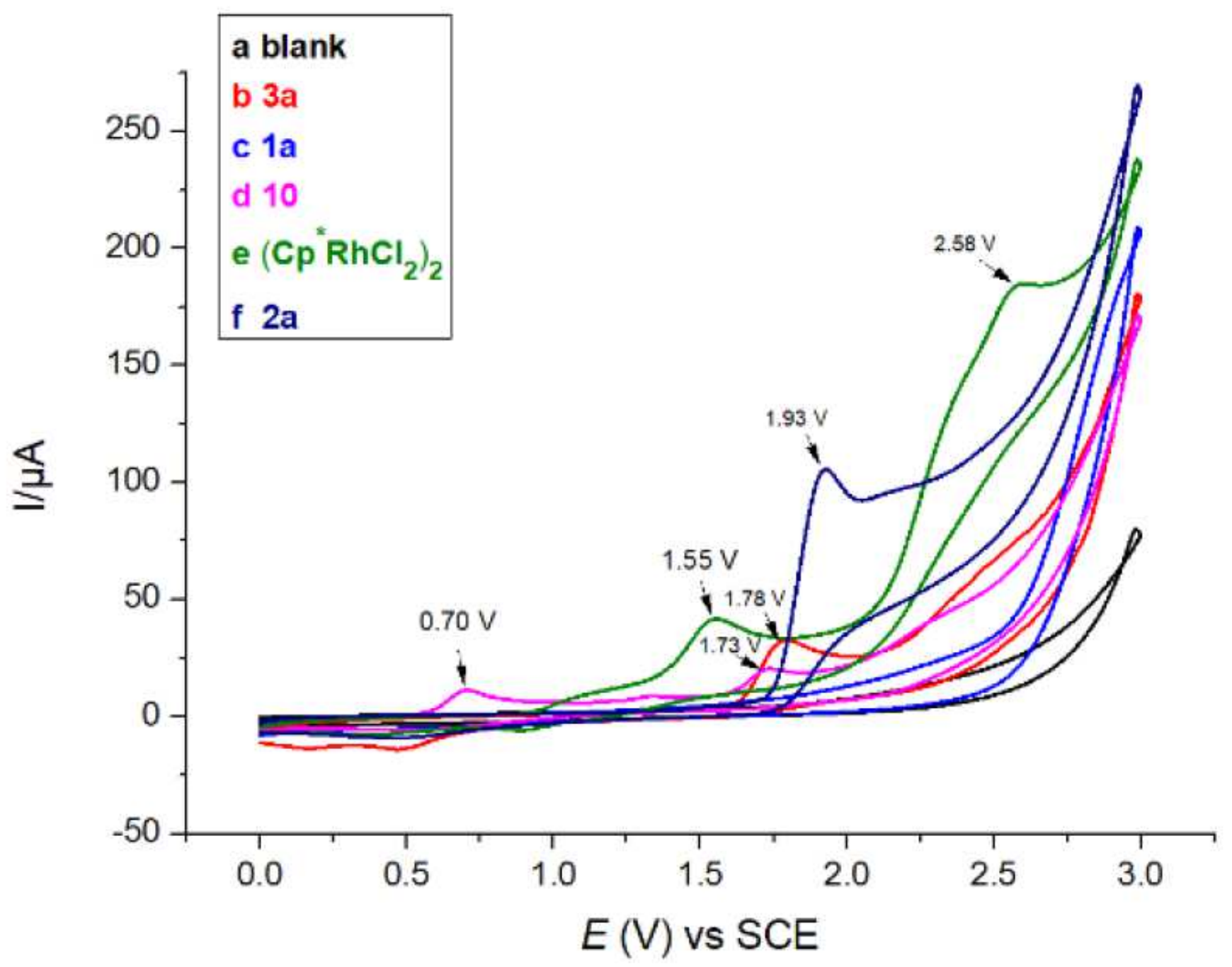

Figure 1

Cyclic Voltametric study. Cyclic voltammograms recorded on a Pt electrode (area $=0.03 \mathrm{~cm} 2$ ) with a scan rate of $100 \mathrm{mV} \mathrm{s}-1$ : (a) MeCN containing $0.1 \mathrm{M}$ n-Bu4NPF6; (b) MeCN containing $0.1 \mathrm{M} \mathrm{n}$-Bu4NPF6, after addition of $4 \mathrm{mM} 3 \mathrm{a}$; (c) MeCN containing $0.1 \mathrm{M}$ n-Bu4NPF6, after addition of $4 \mathrm{mM} 1 \mathrm{a}$; (d) MeCN containing $0.1 \mathrm{M} \mathrm{n}$-Bu4NPF6, after addition of $4 \mathrm{mM} 10$; (e) MeCN containing $0.1 \mathrm{M} \mathrm{n}$-Bu4NPF6, after addition of $4 \mathrm{mM}$ complex (Cp*RhCl2)2; (f) MeCN containing $0.1 \mathrm{M} \mathrm{n}$-Bu4NPF6, after addition of $4 \mathrm{mM}$ 2a. 


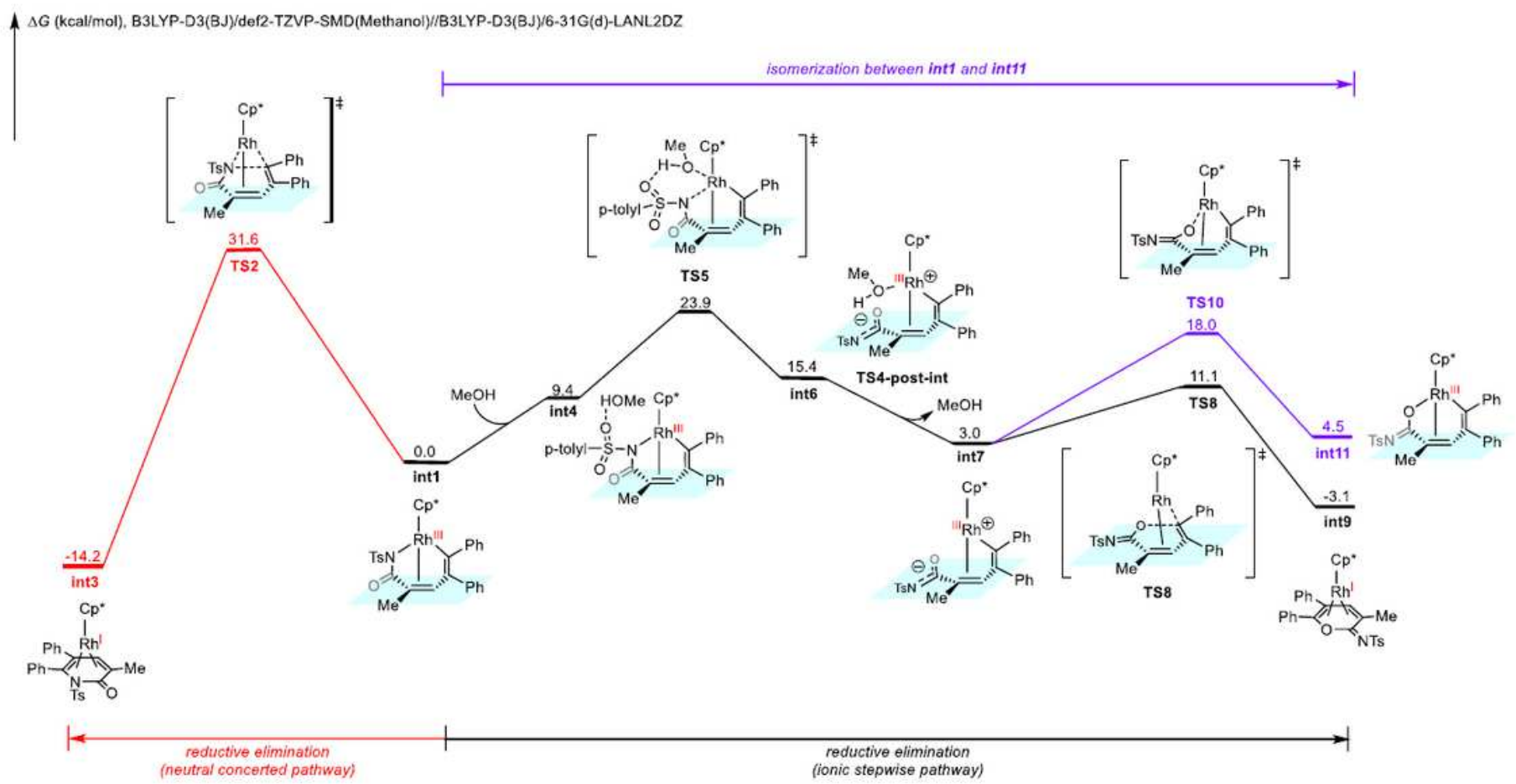

Figure 2

DFT-computed free energy changes in competing for reductive elimination pathways from sevenmembered ring vinyl-rhodium intermediate when $\mathrm{N}$-tosyl acrylamide 1 a was employed as the substrate. 


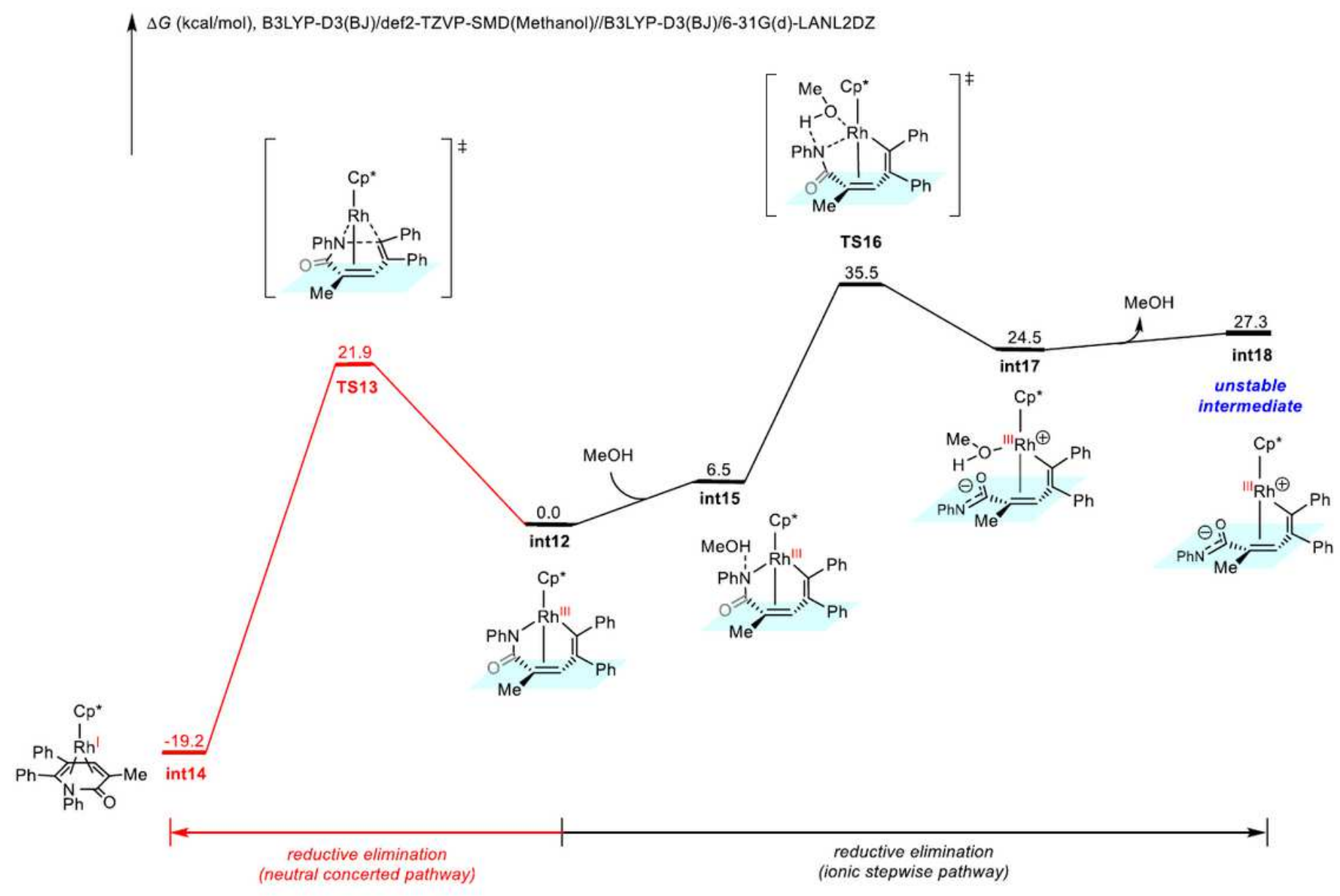

Figure 3

DFT-computed free energy changes in competing for reductive elimination pathways from sevenmembered ring vinyl-rhodium intermediate int 10 when $\mathrm{N}$-phenyl acrylamide $1 \mathrm{~b}$ was employed as the substrate.

\section{Supplementary Files}

This is a list of supplementary files associated with this preprint. Click to download.

- supportinginformation107.pdf 